\title{
RECENZIÓ A \\ „GYERMEKEK, TANÁROK, ISKOLÁK - EGYKORON ÉS MA. TANULMÁNYOK A 90 ÉVES MÉSZÁROS ISTVÁN TISZTELETÉRE” CÍMÜ KÖNYVRŐL
}

A recenzió szerzője:

Almási Brigitta (Drs)

Eszterházy Károly Egyetem

Szerző e-mail címe:

brigitta.almasi1989@gmail.com
Lektor:

Katona Krisztina $(\mathrm{PhD})$

Gál Ferenc Egyetem

Jaskóné Gácsi Mária (PhD)

Miskolci Egyetem

...és további két anonim lektor

Almási Brigitta (2020): Recenzió a „Gyermekek, tanárok, iskolák - egykoron és ma. Tanulmányok a 90 éves Mészáros István tiszteletére" című könyvről. OxIPO - interdiszciplináris tudományos folyóirat, 2020/3, 109-113. doi: 10.35405/OXIPO.2020.3.109

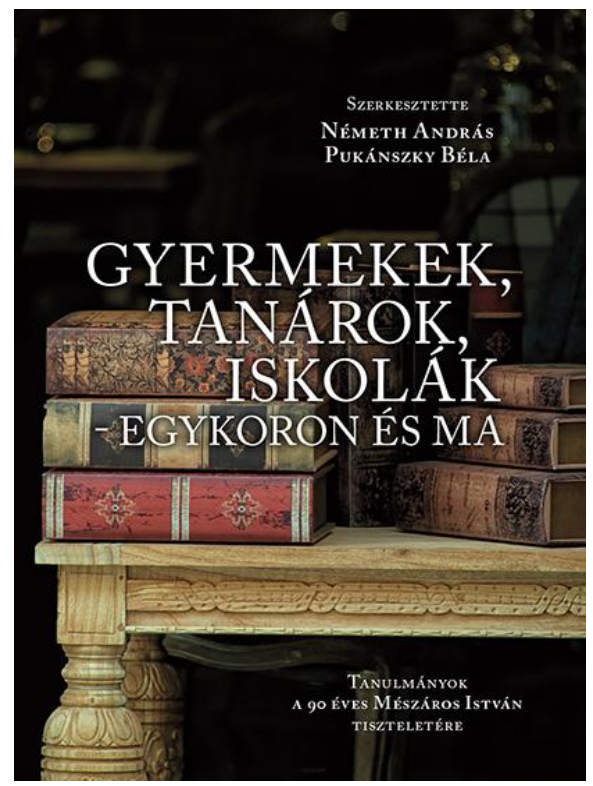

A recenzió alapjául szolgáló mü:

Németh András és Pukánszky Béla (szerk.) (2017): Gyermekek, tanárok, iskolák - egykoron és ma. Tanulmányok a 90 éves Mészáros Istuán tiszteletére. ELTE Pedagógiai és Pszichológiai Kar, Budapest. ISBN 978-963-284-855-6

Kulcsszavak: neveléstörténet, iskola Diszciplína: pedagógia

Bibliography of the subject of this recension:

Németh, András \& Pukánszky, Béla (eds.) (2017): Children, teachers, schools a long time ago and now. Studies in honor of 90 years old István Mészáros. Budapest: ELTE Pedagógiai és Pszichológiai Kar. ISBN 978-963-284-855-6

Keywords: history of education, school Disciplines: pedagogy 
A Gyermekek, Tanárok, Iskolák Egykoron és $M a$ címú tanulmánykötet Németh András és Pukánszky Béla szerkesztésében jelent meg 2017-ben. A kötetben a neveléstudomány olyan jeles kutatóinak és professzorainak tanulmányait olvashatjuk, mint Garai Imre, Golnhofer Erzsébet, Szabolcs Éva, Hegedűs Judit, Kéri Katalin, Mikonya György, Nagy Péter Tibor, Németh András, Nóbik Attila és Pehő Villő.

Garai Imre Teleki Pál, a báró Eötvös József Collegium curátora címú munkájában rávilágít a Collegium szerepére a magyar középiskolai tanári szakma kialakulásában a 1920. század derekán, amely a dulaizmus tudós tanárképzésére épült. A tanulmány részletesen bemutatja Teleki Pál Collegium Curátori tisztségére történő kinevezésének körülményeit, ahol az első világháborút követő országos szinten így a Collegiumban is jelentkező nehézségekkel kellett szembenéznie. A tanulmány művelődéstörténeti szempontból is fontos adalékul szolgál. Garai Imre tanulmányában végig követhetjük a Collegium Teleki Pál törekvését a Cullegium autonómiájáért.

Golnhofer Erzséber és Szabolcs Éva $A$ hagyományok megszakitása, átértelmezése a pedagógiai tankönyvekben az ötvenes évek elsö felében címú munkájukban részletesen olvashatunk a pluralizmus a második világháború utáni időszakban a pedagógia területén való pluralizmus felszámolásáról. A tanulmányban körvonalazódik a szovjet pedagógia hazai megjelenésének aspektusai, majd pedig eljutunk a szovjet pedagó- gia kizárólagosságához. Itt olvashatunk a hazai neveléstudomány átalakulásának folyamatáról, amelyet szovjet mintára alakították át.

A könyvben széles körűen és különböző történelmi korokból emelkednek ki a neveléstudomány, neveléstörténet egyes vonatkozásai. Hegedűs Judit Nők az iskolák élén a 19. sqáąadi Magyarorsqágon címú tanulmányában eme korszak első iskolaigazgatónőinek szerepköreibe vezeti be az olvasót. A téma vezető fonala a női emancipációs mozgalmak hajtóereje, hiszen e mozgalmakban kitüntetett szerepük volt. A tanulmány széleskörűen tárja fel az igazgatónők feladatait, nem pusztán a klasszikus értelemben vett vezetői egyéniséget értjük, hanem sokkal összetettebb, egyfajta írói, publicisztikai szerepköreiket is feltárja a tanulmány. A tanulmáni további részében az igazgatónők közéleti szerepeiről olvashatunk, amelyben a szerző rámutat arra, hogy milyen presztízzsel bírt és a társadalmi ranglétrán milyen helyet foglaltak el e tevékenységet képviselő nők a 19. század végén.

Kéri Katalin Egy páratlan gyerekkortörténeti forrás a reneszánsz. korból: Vives latin nyelvkönyve címú írásában mutatja be az 1492ben, Valenciában született Juan Luis Vives-t és a címben is említett latin nyelvkönyvét. Vives műve a 16. század elején élő gyermekek mindennapjaiba, kérdésköreibe is bepillantást nyújtó dialógusokból áll. Módszertanát tekintve korát meghaladónak tekinthető szerzőről van szó személyében, aki például előtérbe helyezte 
beszédcentrikusságot és túllépett azon a korabeli nyelvtanítási állásponton, miszerint a nyelvtanulás legüdvözítőbb módja korábbi szerzők nyelvi fordulatainak recitálása, utánzása. E latin nyelvkönyv kuriózuma az is, hogy noha 1539-es első megjelenése óta több száz későbbi kiadása ismert és világszerte használatba került, azonban magyar nyelvű fordítása a mai napig nem létezik. A mű időtálló vonatkozásait jól tükrözi Kéri Katalin (idézett mű 49. oldalán) tett megjegyzése is: „A dialógusok szövegei szerint a gyerekek többsége Vives idejében is hasonlóképpen vélekedett az iskoláról, mint manapság: aki már bent volt, kifelé igyekezett, a kicsik képzeletében viszont ez a hely maga volt a mennyország, a káprázatos csodák birodalma...”.

Mikonya György Szempontok az egyetemi nációk kutatásához címú írásában először is a nációk fogalomkörével ismerkedhetünk meg, amelyek egyetemként mást jelentést hordoznak magukban. A tanulmány lépésről lépésre vezeti be az olvasót a nációk szerveződésébe, majd pedig kezdeti törekvéseikről kaphatunk képet. A szerző az egyes európai egyetemek és a nációk kapcsolatának rendszerét mutatja be. Így a párizsi, magyar vonatkozásban a pécsi, bolognai egyetem példáját mutatja be az egyetemi nációk kutatásával kapcsolatban. A tanulmány végigvezeti az olvasót a prágai egyetemen történt nációk okozta incidensen, majd a tanulmány befejező részében a bécsi egyetem példáján jeleníti meg a szerző a nációk megszűnésére.
Nagy Péter Tibor Magyar Állami Oktatáspolitika - a középkorban címú tanulmányában a szerző álláspontja szerint kissé rendhagyóan hangozhat az oktatáspolitika szakkifejezés ebben a kontextusban. Nagy Péter Tibor munkájában az oktatáspolitikát az állam és az egyház viszonyának megvizsgálásával vezeti fel. Ezt követően az állam oktatáspolitikai eszközeire helyeződik a hangsúly és a kolostori és káptalani iskolák állammal való kapcsolatrendszerébe nyerhetünk betekintést. A tanulmányban az államhoz való viszonyulást több szempont mentén vizsgálja a szerző: újabb módszerek alkalmazása az oktatásban, állam és értelmiség kapcsolata.

Németh András Az életreform-kommunák és a reformpedagógiai közösségi nevelés elveinek forrásai és 19. századi elözményei címû munkájában az életreform terminus magyarázatával kezdődik, amely a 19. század azon mozgalmainak összefoglaló definiálására szolgál, amelyek elsősorban NyugatEurópában és Amerikában a modernizációkritikai mozgalmak összefoglalójaként szerepel. A tanulmányban a szerző a kommunamozgalom történeti gyökereitől vezeti az olvasót egészen az ókor, középkor idejétől a romantika életérzéséig. Ezt követően a 19. századi előzményekről olvashatunk, ahol az ipari forradalom következményeinek hatásait mutatja be. A tanulmány az összegzésben rámutat a 20. század kezdetén kibontakozó életreform kibontakozó kommunáira.

A dualizmus kori tanítóképzős neveléstörténeti tankönyveinek kialakulásáról, 
forrásairól írt tanulmányt Nóbik Attila Tanitóképzós neveléstörténeti tankönyveink a dualizmus korában címmel. A szerző rávilágít arra a területre, miszerint a neveléstörténeti tankönyveknek kiemelkedő szerepük van a népoktatási rendszer bemutatásában és a pedagógiai klasszikusok megismertetésében.

A tanulmánykötetet érdemes átlapozni azoknak a kutatóknak is, akik a zenei nevelés történetével foglalkoznak munkájuk során. Pethő Villő Kodály zenei nevelési koncepciójának értelmezési lehetôségei című munkájában. A szerző munkájában részletesen kitér a koncepció pedagógiai sajtóban történő megjelenések fontosságára, valamint arra az aspektusra, hogy a zenei nevelés miként jelenik meg a különféle pedagógiai koncepciókban és iskolakísérletekben. Itt kulcskérdésként szerepel a zenei nevelés szerepe. A tanulmányban a reformpedagógiai kiemelkedő alakjainak munkáját veti össze a szerző Kodály Zoltán zenei nevelési koncepciójával.

A 19. században megjelenő egészségnevelésre vonatkozó ismereteket öleli fel Pukánszky Béla $A$ testi-fiæikai nevelésre, illetve az egészségnevelésre vonatkozó ismeretek megjelenése és kanonizálódása a 19. század elsö évtizedeinek magyar neveléstani kézikönyvekben címmel megjelent tanulmányában. A téma megközelítését Pukánszky Béla a 18-19. századi Magyarországon megjelent neveléstanok és gyakorlati pedagógiai kézikönyvek szerzőivel vezeti fel, mint például Szilasy János, Perlaki Dávid, Tóth Pápai Mihály, Zákány József. A szerző ismerteti tanulmányában a testi nevelés megjelenésének lépéseit a pedagógiában.

Időben előrébb viszi az olvasót Rébay Magdolna Az általános iskola megszervezéséröl szóló rendelet hatása a budapesti református iskolákra című tanulmánya. A szerző tanulmányában kitér a Dunamelléki református egyházkerülethez tartozó iskolák történetére. A tanulmány irányt ad az iskolák átszervezésének felekezeti viszonyokban is megjelenő motívumaihoz. A tanulmány azon része, amely a budapesti református általános iskolák 1945-1948 közötti történetét tárja fel, részletes leírást tartalmaz az iskolaalapítás körülményeiről, és a tanulók létszámainak alakulásával kapcsolatban a források tükrében.

A tanulmánykötetben Sáska Géza Embernek lenni sötét időkeben című munkája rávilágít a marxizmus és leninizmus eszméjével átszőtt szocialista neveléstudomány egyes vonatkozásaira. A szerző a munkájában ismerteti a magyar neveléstudomány pártszerű tudománnyá alakulását. Sáska Géza írásában rámutat arra a lényeges pontra is, miszerint a politika a marxizmus és leninizmus jegyében miként szólt bele a tudományba, majd pedig ennek az ideológiának hanyatlását láthatjuk.

Ugrai János Felbiger és az, ausztriai tevékenysége címmel megjelent tanulmányában megismerhetjük az osztrák népoktatás döntően Felbigerhez köthető fordulatát a 18. század derekán. Ausztriában a népoktatásban bekövetkező változások Felbiger 1774-es meghívásának eredménye lesz. A szerző a tanulmányában részletesen átte- 
kinti a kisiskolák sorsának alakulását és kitér a jozefinizmus évtizedeiben működő elemi iskolázás alakulásra, valamint a lányok nevelésének kérdéseire is.

A tanulmánykötetet Vincze Beatrix $A$ kertmotivum Németh Lásqló pedagógiai és életreform/koncepciójában című tanulmánya zárja. Németh László széles látókörű személyiség volt, noha nem nevezhetjük reformpedagógusnak, mégis sokat tett a Horthy- rendszerben a kultúra továbbadásáért. Vincze Beatrix tanulmányában megismerhetjük Németh László reformpedagógiai koncepcióját, és az életreform kertmotívum egymáshoz való összekapcsolódását. A tanulmány irányt ad a magyar viszonyokra nézve is, ugyanis Németh László pedagógiai reformjával egyúttal a magyarság életreformját is megalkotta. 